\title{
The Effect of Apex Pruning on Vegetative and Generative Growth of Roselle (Hibiscus sabdariffa L.)
}

\author{
Slamet Susanto*, Titistyas Gusti Aji, and Arifah Rahayu
}

Diterima 23 Agustus 2013/Disetujui 21 Oktober 2013

\begin{abstract}
The experiment was aimed at studying the effect of number of branch on vegetative and generative growth of roselle. The experiment was conducted at Cikabayan Experimental Farm from February to June 2009. The experiment was arranged in randomized complete block design with single factor and consisted of four levels of pruning: control (without pruning), apex pruning with 5 branches, apex pruning with 10 branches, and apex pruning with 15 branches, each with three replications. The result indicated that pruning with different number of branch gave effect on decreasing on some variables of vegetative and generative growth of roselle. Plants experienced apex pruning with 15 branches did not show any differences on number of primary stems, number of secondary stems, number of leaves, number of flowers, fresh and dry weight of calyxes, and anthocyanin content in calyxes. Plants experienced pruning with different number of branches tended to have higher anthocyanin content than those on control. Generally, plants with 15 primary branches gave the best effect on both vegetative and generative growth of roselle.
\end{abstract}

Keywords: Hibiscus sabdariffa L., pruning, branch, growth

\begin{abstract}
ABSTRAK
Penelitian ini bertujuan untuk mempelajari pengaruh jumlah cabang pada pertumbuhan vegetatif dan generatif rosela. Penelitian dilaksanakan di Kebun Percobaan Cikabayan pada bulan Februari sampai Juni 2009. Percobaan disusun dalam rancangan acak lengkap dengan faktor tunggal dan terdiri dari empat tingkat pemangkasan: kontrol (tanpa pemangkasan), pemangkasan pucuk dengan 5 cabang, pemangkasan pucuk dengan 10 cabang, dan pemangkasan pucuk dengan 15 cabang, masing-masing dengan tiga ulangan. Hasil penelitian menunjukkan bahwa pemangkasan dengan nomor yang berbeda dari cabang memberi efek pada penurunan pada beberapa variabel pertumbuhan vegetatif dan generatif rosela. Tanaman dengan pemangkasan pucuk pada 15 cabang tidak menunjukkan perbedaan pada jumlah batang utama, jumlah sekunder batang, jumlah daun, jumlah bunga, berat segar dan kering calyxes, dan konten antosianin di calyxes. Tanaman mengalami pemangkasan dengan nomor yang berbeda dari cabang cenderung memiliki konten antosianin lebih tinggi dibandingkan pada kontrol. Umumnya, tanaman dengan 15 cabang utama memberikan efek terbaik pada kedua pertumbuhan vegetatif dan generatif rosela.
\end{abstract}

Kata kunci: Hibiscus sabdariffa L., pemangkasan, cabang, pertumbuhan

\section{INTRODUCTION}

Indonesian tropical forest has the richest diversity of plants in the world. There are more than 30000 species of plants that 940 among them are known to have special quality in healing (Karmawati et al., 1996). Nowadays, the development of tonic and traditional medicine industries are rapidly growing. The utilization of medicinal plants will be keep rising, both as preventive, curative, and rehabilitative purposes. The rising of the utilization of medicinal plants also caused by the society's preference on inquiring for alternative therapy using natural materials as known as back-to-nature phenomenon.

Roselle (Hibiscus sabdariffa L.) is now broadly used as food substance with medicinal property. As food, young leaves of roselle can 
be consumed as salad. Other than foods, this plant can be processed as beverages. Part of the plants that can be processed as beverages is its calyx. In the processing, calyxes of roselle can be made into juice, herb tea, syrup, jam, mixture on salad, pudding, and any other refreshing beverages. From health perspective, roselle comes in useful in producing many medicinal products. Stewed calyxes have medicinal property as diuretic, cholerectic, febrifugal, hypotensive, in reducing the blood viscosity, and increasing the intestine's peristalsis (Morton, 1987).

Roselle can grow in variety of soil with good texture and drainage. To produce roselle with good quality, a cultivation technique to support its balance on vegetative and generative growth is needed. Maintenance of selected branches through pruning supposed to improve the balance of vegetative and generative growth by improving photosynthesis capacity of the leaves. Olasantan (2007) reported that in pruned plants, mutual shading of leaves would have reduced, and consequently the amounts of light energy available for growth and development of the plants would have increased since the remaining leaves would be photosynthesizing more than they would be respiring. This experiment is aimed at studying the response of vegetative and generative growth of roselle experienced pruning with different number of branch. Quantity and quality of calyxes produced are observed.

\section{MATERIALS AND METHODS}

The experiment was conducted at Cikabayan Experimental Farm of Bogor Agricultural University from February to June 2009. The experimental plant used in this experiment was No. 1 red accession roselle. The experiment was arranged in randomized complete block design with single factor and consisted of four levels of pruning: Control/without pruning $(\mathrm{C} 1)$, apex pruning with 5 branches $(\mathrm{C} 2)$, apex pruning with 10 branches (C3), and apex pruning with 15 branches $(\mathrm{C} 4)$. Each treatment had 3 replications, there were 12 experimental units. The data were analyzed using the F-test. For the parameters showing significant differences, the means were compared by the Duncan Multiple Range Test at 0.05 .
Roselle used in this experiment was Red Roselle accesion. Before planting, seeds of roselle were induced to germinate by soaking the seeds in the water overnight. Seeds are planted in the polybag using media consisted of a mixture of soil and manure with comparison of 5:1. Only one plant maintenanced in each polybag. The polybags then placed in the open field with spacing of $1 \mathrm{~m} \times 1.5 \mathrm{~m}$.

Irrigation was done manually once a day. Weeds and pests control was done as standard as adapted to the land condition. Fertilization was done using single fertilizer of $\mathrm{N}$, P, and $\mathrm{K}$. Dosage of $\mathrm{N}$ fertilizer was 30 gram polybag ${ }^{-1}$. Application of $\mathrm{N}$ fertilizer was done twice, half was applied when the plants were at the age of 4 weeks after planting and the rest was applied when the plants were at the age of 10 weeks after planting. $\mathrm{P}$ and $\mathrm{K}$ fertilizer of 15 gram polybag ${ }^{-1}$ respectively were applied once when the plants were at the age of 4 weeks after planting. Application of N, P, and K fertilizer was done by sinking the fertilizers around the plants by radius $10 \mathrm{~cm}$ from the stem of the plants.

Apex and branch pruning were done when the plants were at the age of 7 weeks after planting using shears, leaving a number of branches according to treatments. After pruning, the pruned part of the plants was dabbed with liquid wax to prevent excessive evaporation and to reduce the risk of disease infection through the pruning injury.

Harvesting calyxes was conducted regularly every week started at 60 days after the flowers bloomed. Calyxes were harvested by cutting using shears. Harvest was done five times during the experiment and done when the calyxes reached maximum growth.

Observation was done at vegetative phase and generative phase. At vegetative phase observation was subjected to height of plants, number of secondary branches, number of leaves, and leaf area. Observation was done every week, starting from the age of 3 weeks after planting. At generative phase, observation was conducted on the number of flowers, number of harvested calyxes, diameter of calyx, fresh weight and dry weight of calyxes, and anthocyanin content using the method of Sims and Gamon (2002). Observation was done every week starting from the week when $75 \%$ of population had produced inflorescent. At the 
end of the experiment, fresh weight and dry weight of canopy and root were also observed.

\section{RESULTS}

\section{General Condition}

The average rainfall during experiment was $346.9 \mathrm{~mm} \mathrm{month}^{-1}$ with $25.8{ }^{0} \mathrm{C}$ average temperature and $84 \%$ average relative humidity. Minimum average temperature was $25.1{ }^{\circ} \mathrm{C}$ occurred on February while maximum average temperature was $26.2{ }^{\circ} \mathrm{C}$ occurred on April. Roselle grew healthy with number of primary branches each was 5,10 and 15 on treated plants, while for the control plants achieved 27 branches at the end of experiment (Figure 1). Height of plants was ranging from 73.0 to 73.8 $\mathrm{cm}$ for the treated plants, while the control plants achieved $105.2 \mathrm{~cm}$ (Figure 2).

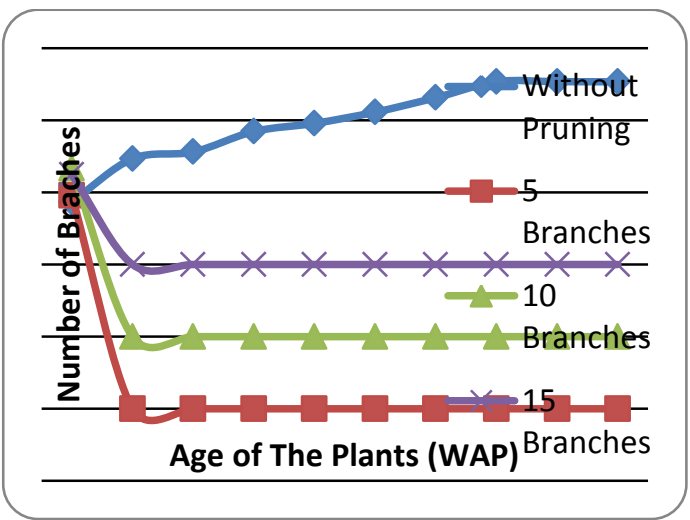

Figure 1. Number of primary stems of roselle as affected by number of branch

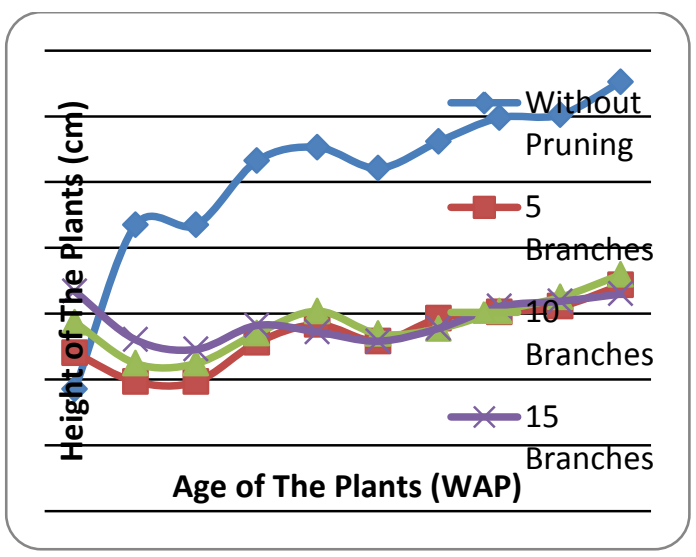

Figure 2. Height of roselle as affected by number of branch $(\mathrm{cm})$

\section{Number of Secondary Branches and Leaves}

Number of secondary branches on plants without pruning at 15 weeks after planting reached 124.4 branches, significantly higher than those on plants with 5 branches and 10 branches that showed 82.2 and 100.0 branches respectively (Table 1). Number of secondary branch on plants with 15 primary branches treatment was 112.4, did not show any differences as compared with those on plants without pruning. The same tendency also occurred on the number of leaves which showed that on treated plants with 5 and 10 branches produce 407.1 and 435.1 leaves respectively, significantly lower than those on plants without pruning with number of leaves reached 515.8 leaves. While plants with 15 branches produce 474.0 leaves showed no significant differences as compared with the plants without pruning. Although total leaf area ranged from $34832-41346 \mathrm{~cm}^{2}$, showed insignificant different among the treatments, leaf area of plants with 5 branches was significantly higher than those of plants without pruning (Table 1).

\section{Fresh and Dry Weight of the Canopy and Root}

Apex pruning gave significant effect on fresh weight and dry weight of the canopy. The measurement results showed that plants without pruning have the highest fresh weight and dry weight of the canopy, those are $693.33 \mathrm{~g}$ and $173.14 \mathrm{~g}$, respectively. Apex pruning treatments with 5,10 , and 15 branches have fresh weight of the canopy of $525.56 \mathrm{~g}, 566.11 \mathrm{~g}$ and $606.78 \mathrm{~g}$ respectively. While the dry weight of the canopy in apex pruning treatment with 5,10 , and 15 branches are $114.39 \mathrm{~g}, 141.48 \mathrm{~g}$, and $146.70 \mathrm{~g}$ respectively (Table 2). Apex pruning also gave significant effect on fresh weight and dry weight of the root. The measurement results showed that unpruned plants have the highest fresh weight and dry weight of the root, those are $63.58 \mathrm{~g}$ and $19.67 \mathrm{~g}$, respectively. Apex pruning treatments with 5,10 , and 15 branches have fresh weight of the root of $37.78 \mathrm{~g}, 49.89 \mathrm{~g}$ and $50.11 \mathrm{~g}$ respectively. While the dry weight of the root in apex pruning treatment with 5, 10 , and 15 branches are $14.23 \mathrm{~g}, 15.82 \mathrm{~g}$, and $15.84 \mathrm{~g}$ respectively (Table 2 ). 


\section{Number of Flower and Fruit}

Apex pruning gave significant effect on number of flowers. The highest number of total flower achieved by plants without pruning, which were 1894.7 flowers and significantly different as compared with those produced by plants with 5 branches that showed only 1082.0 flowers. Number of total flowers on 10 and 15 branches were 1580.3 and 1605.0 flowers respectively (Table 3 ) did not show any significant difference as compared with unpruned plants. The same tendency was also found on number of fruit harvested. On the contrary, the highest calyx diameter was observed on plants with 5 branches, which was $5.32 \mathrm{~cm}$ and significantly different as compared with those of plants without pruning, which was $4.52 \mathrm{~cm}$. Diameter of calyx of plants with 10 and 15 branches were $5.15 \mathrm{~cm}$ and $5.24 \mathrm{~cm}$ respectively (Table 3 ).

\section{Fresh and Dry Weight of Harvested Calyxes}

Apex pruning treatment did not give any significant effect on total fresh weight of calyxes. Total fresh weight of calyxes ranges from $1171.5 \mathrm{~g}$ to $1991.3 \mathrm{~g}$ (Table 4). The highest total fresh weight was achieved by plants without pruning, although the differences were not significant. Number of branch treatment gave significantly effect on total dry weight of calyxes. The highest total dry weight was achieved by plants without pruning, which was $187.1 \mathrm{~g}$, showed significant differrence as compared with those on plants with 5 and 10 branches that showed only $112.7 \mathrm{~g}$ and 124.2 g respectively. Dry weight of calyxes on plants with 15 branches was $166.6 \mathrm{~g}$ (Table 5) showed no difference with plants without pruning.

\section{Anthocyanin Content}

Apex pruning treatments gave effect significantly on anthocyanin content in calyxes of roselle. Anthocyanin content in calyxes of treated roselle ranged from 0.37 to $0.41 \mathrm{mmol} \mathrm{g}^{-1}$, while on unpruned plants was only $0.32 \mathrm{mmol} \mathrm{g}^{-1}$. The highest anthocyanin content achieved by 5 branches treatment, which was $0.41 \mathrm{mmol} \mathrm{g}^{-1}$ (Table 6).

Table 1. Number of secondary stems, number of leaves, leaf area, and total leaf area.

\begin{tabular}{lcccc}
\hline \multicolumn{1}{c}{ Treatments } & $\begin{array}{c}\text { Number of } \\
\text { Secondary } \\
\text { Stems }\end{array}$ & $\begin{array}{c}\text { Number of } \\
\text { Leaves }\end{array}$ & Leaf Area $\left(\mathbf{c m}^{2}\right)$ & $\begin{array}{c}\text { Total Leaf Area } \\
\left(\mathbf{c m}^{2}\right)\end{array}$ \\
\hline $\begin{array}{l}\text { Without Pruning } \\
\text { Pruning with 5 }\end{array}$ & $129.00 \mathrm{a}$ & $696.78 \mathrm{a}$ & $49.99 \mathrm{~b}$ & $34832 \mathrm{a}$ \\
$\begin{array}{l}\text { Branches Left } \\
\text { Pruning with 10 }\end{array}$ & $95.89 \mathrm{~b}$ & $486.78 \mathrm{~b}$ & $76.34 \mathrm{a}$ & $37160 \mathrm{a}$ \\
$\begin{array}{l}\text { Branches Left } \\
\text { Pruning with 15 }\end{array}$ & $106.67 \mathrm{ab}$ & $630.00 \mathrm{a}$ & $65.63 \mathrm{ab}$ & $41346 \mathrm{a}$ \\
Branches Left & $115.67 \mathrm{ab}$ & $651.67 \mathrm{a}$ & $62.60 \mathrm{ab}$ & $40794 \mathrm{a}$ \\
\hline
\end{tabular}

Means within a row followed by different letters are significantly different $(\mathrm{p}<0.05)$ according to DMRT test.

Table 2. Fresh and dry weight of canopy and root at the end of experiment

\begin{tabular}{|c|c|c|c|c|c|}
\hline \multirow{2}{*}{ Treatment } & \multicolumn{2}{|c|}{ Canopy Weight } & \multicolumn{2}{|c|}{ Root Weight } & \multirow{2}{*}{$\begin{array}{c}\text { Ratio } \\
\text { Canopy/Root }\end{array}$} \\
\hline & Fresh & Dry & Fresh & Dry & \\
\hline Without Pruning & $693.33 \mathrm{a}$ & $173.14 \mathrm{a}$ & $63.58 \mathrm{a}$ & $19.67 \mathrm{a}$ & 8.80 \\
\hline $\begin{array}{l}\text { Pruning with } 5 \\
\text { Branches Left }\end{array}$ & $525.56 \mathrm{~b}$ & $114.39 \mathrm{~b}$ & $37.78 \mathrm{~b}$ & $14.23 \mathrm{~b}$ & 8.03 \\
\hline $\begin{array}{l}\text { Pruning with } 10 \\
\text { Branches Left }\end{array}$ & $566.11 \mathrm{~b}$ & $141.48 \mathrm{ab}$ & $49.89 \mathrm{ab}$ & $15.82 \mathrm{~b}$ & 8.94 \\
\hline $\begin{array}{l}\text { Pruning with } 15 \\
\text { Branches Left }\end{array}$ & $606.78 \mathrm{ab}$ & $146.70 \mathrm{a}$ & $50.11 \mathrm{ab}$ & $15.84 \mathrm{~b}$ & 9.26 \\
\hline
\end{tabular}

Means within a row followed by different letters are significantly different $(\mathrm{p}<0.05)$ according to DMRT test. 
Table 3. Number of flower and fruit and calyx diameter

\begin{tabular}{lccc}
\hline \multicolumn{1}{c}{ Treatment } & $\begin{array}{c}\text { Number of Flower } \\
\text { per Plant }\end{array}$ & $\begin{array}{c}\text { Number of Harvested } \\
\text { Calyx }\end{array}$ & $\begin{array}{c}\text { Diameter of Calyx } \\
\text { (cm) }\end{array}$ \\
\hline $\begin{array}{l}\text { Without Pruning } \\
\text { Pruning with 5 }\end{array}$ & $1894.70 \mathrm{a}$ & $579.82 \mathrm{a}$ & $4.52 \mathrm{~b}$ \\
$\begin{array}{l}\text { Branches Left } \\
\text { Pruning with 10 }\end{array}$ & $1082.00 \mathrm{~b}$ & $351.67 \mathrm{~b}$ & $5.32 \mathrm{a}$ \\
$\begin{array}{l}\text { Branches Left } \\
\text { Pruning with 15 }\end{array}$ & $1580.30 \mathrm{ab}$ & $403.00 \mathrm{~b}$ & $5.15 \mathrm{ab}$ \\
Branches Left & $1605.00 \mathrm{ab}$ & $495.00 \mathrm{ab}$ & $5.24 \mathrm{ab}$ \\
\hline
\end{tabular}

Means within a row followed by different letters are significantly different $(\mathrm{p}<0.05)$ according to DMRT test.

*Fruit with normal calyxes

Table 4. Fresh and dry weight of calyxes

\begin{tabular}{lcccc}
\hline \multirow{2}{*}{ Treatment } & \multicolumn{2}{c}{ Fresh Weight } & \multicolumn{2}{c}{ Dry Weight } \\
\cline { 2 - 5 } & Per Plant & Per Calyx & Per Plant & Per Calyx \\
\hline Without Pruning & $1857.29 \mathrm{a}$ & $2.95 \mathrm{~b}$ & $174.50 \mathrm{a}$ & $0.26 \mathrm{~b}$ \\
Pruning with 5 & $1171.50 \mathrm{~b}$ & $3.33 \mathrm{a}$ & $112.65 \mathrm{~b}$ & $0.32 \mathrm{a}$ \\
$\begin{array}{l}\text { Branches Left } \\
\text { Pruning with 10 }\end{array}$ & $1303.90 \mathrm{ab}$ & $3.24 \mathrm{ab}$ & $124.24 \mathrm{~b}$ & $0.31 \mathrm{a}$ \\
$\begin{array}{l}\text { Branches Left } \\
\text { Pruning with 15 }\end{array}$ & $1553.20 \mathrm{ab}$ & $3.14 \mathrm{ab}$ & $166.64 \mathrm{ab}$ & $0.31 \mathrm{a}$ \\
Branches Left & & & & \\
\hline
\end{tabular}

Means within a row followed by different letters are significantly different $(\mathrm{p}<0.05)$ according to DMRT test.

Table 5. Anthocyanin content of roselle as affected by pruning

\begin{tabular}{lcc}
\hline \multicolumn{1}{c}{ Treatment } & $\begin{array}{c}\text { Anthocyanin Content } \\
(\mathbf{m m o l} / \mathbf{g})\end{array}$ & $\begin{array}{c}\text { Anthocyanin Content per Plant } \\
(\mathbf{m m o l})\end{array}$ \\
\hline Without Pruning & $0.32 \mathrm{~b}$ & 55.84 \\
Pruning with 5 Branches Left & $0.41 \mathrm{a}$ & 46.19 \\
Pruning with 10 Branches Left & $0.38 \mathrm{ab}$ & 47.21 \\
Pruning with 15 Branches Left & $0.37 \mathrm{ab}$ & 61.65 \\
\hline
\end{tabular}

Means within a row followed by different letters are significantly different $(\mathrm{p}<0.05)$ according to DMRT test.

\section{DISCUSSIONS}

Pruning is one of the ways of breaking apical dominance. One of the effects of pruning is the increasing growth of primary branch. On plants experienced pruning, there was no addition on number of primary branchs but the stems left keep growing and become long. This was due to the improvement in light interception that possibly resulted in an improvement in vegetative development (Olasantan, 2007).

Numbers of leaves on plants experienced pruning were less than plants without pruning. This was in accordance with Dainy (2006) that reported that Gynura procumbens plants without pruning have more number of leaves because the growth processes were not disturbed by the injury caused by pruning. Gardner et al. (1991) explained that the distribution of product of photosynthesis is delivered to parts of plant that are closest to source. During vegetative phase, portions of product of photosynthesis are kept stored in the tissues for the process of cell maintenance and the rest were translocated to the vegetative utilization areas. In this experiment, number of primary stems on plants experienced pruning was lower than those of plants without pruning. The more number of stems enabled leaves to grow more. This case presumed to cause the number of 
leaves on plants experienced pruning tended to be less than those of plants without pruning.

According to Kozlowski et al. (1991) at the beginning of the growth period, leaf area of plants experienced pruning decreased then increased rapidly during the growth period. Frequently, leaf area of plants experienced pruning will be wider at the end of the season than plants without pruning. Although pruning treatment did not significantly affect total leaf area, plants experienced pruning have higher total leaf area than plants without pruning. In addition, leaf area on the plant with 5 branches was higher than plants without pruning. This is in line with Olasantan and Salau (2008) that stated that pruning led to an increase in leaf area of okra and the increasing of leaf area depended on the severity of the pruning. The increase in leaf area was caused by the mechanism of the plant to compensate the lost of leaf due to pruning.

Canopies are all parts of the plant that are above ground, consisting of trunk, branches, leaves, and flowers. To obtain the maximum rate of plant growth, there must be an adequate number of leaves in the canopy to absorb sunlight. James (1973) stated that the increase in dry weight of plants mainly depends on the photosynthetic activity of plants. Gardner et al. (1991) stated that crop production basically depends on the size and efficiency of the photosynthetic system. The less number of leaves will also decrease photosynthesis activity. Apex pruning treatment done in this research will affect the size of the plant, such as plant height, number of branches, number of leaves, and number of flowers. Reduced number of leaves will affect plant growth. Leaves as the main photosynthetic organ has an important role in generating photosynthate for food supplies and also for plant growth.

In addition to the canopy, the root is also an important organ needed for plant growth. Gardner et al. (1991) stated that the length and circumference of the root growth is generally associated with the growth of shoot length and circumference. In this experiment, apex pruning causing obstruction in shoots growth, and then obstructing root growth. This is in line with Gardner et al. (1939) that reported that pruning the peach crop has reduced root growth nearly doubled compared to plants that are not pruned.
Number of flowers was increasing gradually although followed by moulting on parts of the flower buds. Healthy flower buds are red but unhealthy flower buds are yellow and moult. The moulting of the flower buds were assumed that there was a high competition among the organs in accomplishment of required assimilates. The beginning of the reproductive phase is thus characterized by the simultaneous presence of vegetative and reproductive sinks, probably resulting in strong competition for assimilates (Jeuffroy and Warembourg, 1991).

The criteria of calyxes that are ready to be harvested are already reached the age for harvesting, which is 60 days after blooming; big enough in size; and bright red in colour. The size of calyx can also be used as standard of ripeness. Calyxes with 5.0-6.0 cm long and $4.5-6.0 \mathrm{~cm}$ diameter are big enough and ready to be harvested. In the process of ripening, chlorophyll is degraded and yellow orange carotenoid and red lycopene are synthesized (Moneruzzaman et al., 2008). Calyxes that are ready to be harvested are bright red because they are rich in anthocyanin in the calyxes.

Total fresh weight and dry weight of calyxes were affected by some factors, one of them is number of flowers. The treatments that were done in this experiment affected the number of flowers formed. On plants that did not experience pruning and on treated plants with 15 branches, number of flowers formed was higher than other treatment. The reduction in the number of flowers on plants experienced pruning could be due to some factors. These include reduction in the numbers of secondary branches and leaves and consequently the photosynthetic area of the treated plants and the amount of assimilate available for developing flowers (Olasantan, 2007).

According to Craker and Wetherbee (1973), light-induced anthocyanin synthesis in plant tissue involves a series of biochemical reactions. Some of these reactions require light energy while others proceed in the dark after the initial light stimulation. Moneruzzaman et al. (2008) also reported that the synthesis of pigments depends on light and temperature. Number of branch treatments caused the crown of the plants open ended so the acceptance of light by the parts of the plant became more optimal. Salisbury and Ross (1995) added that the sunlight accelerate the anthocyanin synthesis 
in the organs without photosynthesis activity, such as on the leaves in autumn and on the sepals. Apex pruning and maintenance of number of branch caused the sunlight accepted by the calyxes of roselle became optimal so that could accelerate the anthocyanin synthesis in the organs.

\section{CONCLUSION}

As conclusion, apex pruning with different number of branches gave effect in decreasing some of variables of vegetative and generative growth of roselle. Plants experienced pruning with 15 branches did not show any differences on number of primary stems, number of secondary stems, number of leaves, number of flowers, number of harvested calyxes, and fresh weight and dry weight of calyxes. Plants experienced pruning tended to have higher anthocyanin content than plants without pruning. Generally, plants with 15 branches gave the best effect on vegetative and generative growth of roselle.

\section{REFERENCES}

Craker, L.E., P.J. Wetherbee. 1973. Ethylene, light, and anthocyanin synthesis. Plant Physiol. 51: 436-438.

Dainy, N.C. 2006. Produksi dan kandungan flavonoid daun Sambung Nyawa (Gynura procumbens [Lour.] Merr.) pada berbagai tingkat naungan dan umur pemangkasan. Tesis. Program Studi Agronomi. Fakultas Pertanian. Institut Pertanian Bogor. Bogor.

Gardner, F.P., R.B. Pearce, R.L. Mitchell. 1991. Fisiologi Tanaman Budidaya. Universitas Indonesia Press. Jakarta.

Gardner, V.R., F.C. Bradford, H.D. Hooker. 1939. The Fundamentals of Fruit Production. McGraw-Hill Book Company Inc. New York.

James, W.O. 1973. An Introduction to Plant Physiology $7^{\text {th }}$ Edition. Oxford University Press. London.
Jeuffroy, M.H., F.R. Waremboug 1991. Carbon transfer and partitioning between vegetative and reproductive organs in Pisum sativum L. Plant Physiol. 97: 440-448.

Karmawati, E., D.S. Effendi, P. Wahid. 1996. Potensi, peluang, dan kendala pengembangan agroindustri tanaman obat. Prosiding Forum Konsultasi Strategi dan Koordinasi Pengembangan Agroindustri Tanaman Obat. Balai Penelitian Tanaman Rempah dan Obat. Bogor. 1: 23-41.

Kozlowski, T.T., P.J. Kramer, S. G. Pallardy. 1991. The Physiological Ecology of Woody Plants. Academic Press Inc. California.

Moneruzzaman, K.M., A.B. M.S. Hossain, W. Sani, M. Saifuddin. 2008. Effect of stages of maturity and ripening conditions on the physical characteristics of tomato. American Journal of Biochemistry and Biotechnology. 4(4): 329-335.

Morton, J. 1987. Roselle, p. 281-286. In J.F. Morton (Ed.). Fruits of Warm Climates.Miami.http://www.zulfandewa ntara.com [21 September 2008].

Olasantan, F.O., A.W. Salau. 2008. Effect of pruning on growth, leaf yield and pod yields of okra (Abelmoschus esculentus (L.) Moench). Journal of Agricultural Science. 146: 93-102.

Olasantan, F.O. 2007. Apical shoot harvest affects growth and apical shoot and fruit yields of pumpkin (Cucurbita maxima Duch. Ex. Lam.). Journal of Vegetable Science. 12: 73-87.

Salisbury, F.B., C.W. Ross. 1995. Fisiologi tumbuhan jilid I, II, III. Terjemahan dari: Plant Physiology. Penerjemah : D. R. Lukman dan Sumaryono. Penerbit ITB Bandung. Bandung.

Sims, D.A., J.A. Gamon. 2002. Relationship between leaf pigment content and spectral reflectance across a wide range of species, leaf structure, and developmental stages. Remote Sensing of Environment. 81: 337-354. 